\title{
Identifikasi Telur Cacing Hookworm, Toxocara vitulorum pada Feses Peternak Sapi dan Feses Sapi di Peternakan Sapi Dusun Karangnongko, Boyolali
}

\author{
Identification Worm Eggs of Hookworm, Toxocara vitulorum on Breedersfeaces's Andcows Feaces's \\ in The Farm Cow at Karangnongko Village, Boyolali
}

Frederica U. Sihombing dan Tri Mulyowati*

Fakultas Ilmu Kesehatan, Universitas Setia Budi Surakarta

*Corresponding author: trimulyowatiusb81@gmail.com

\begin{abstract}
ABSTRAK
Sapi bermanfaat untuk menghasilkan susu. Kondisi sapi penghasil susu harus sehat dan tidak terinfeksi cacing parasit. Infeksi cacing parasit yang dapat menyerang sapi dari kelas Nematoda dan Cestoda. Kerugian bila hewan ternak terinfeksi cacing usus parasit yaitu pertumbuhan sapi muda terhambat, berat badan sapi menurun, penurunan kualitas daging, penurunan produksi susu pada sapi perah, dan beresiko jika menularkan penyakit pada manusia.Tujuan penelitian adalah untuk mengetahui adanya telur cacing Hookworm, Toxocara vitulorum, pada feses sapi dan peternak sapi di Dusun Karangnongko, Boyolali. Pengambilan sampel menggunakan teknik random sampling. Penelitian dilakukan di laboratorium Parasitologi Universitas Setia Budi Surakarta metode langsung yaitu menggunakan lugol $2 \%$ dan diamati secara mikroskopis. Hasil penelitian prosentase positif pada feses sapi adalah Hookworm sebesar 8\%, Toxocara vitulorum 4\% sedangkan pada feses peternak tidak ditemukan infeksi telur cacing Hookworm, Toxocara vitulorum.
\end{abstract}

Kata kunci: Telur cacing Hookworm, Toxocara vitulorum, Sapi.

\begin{abstract}
Cows are useful to produce milk. Condition cows ofmilk producers should be healthy and not infected with parasitic worms. Parasitic worm infections that can attack cows from the Nematoda and Cestoda classes. Disadvantages when livestock infected intestinal worms parasiticis the growth of young cows is inhibited, cow weight decreased, decreased meat quality, decreased milk production in dairy cattle, and risk if it transmit the disease to humans. The purpose of this research is to know the existence of egg wormHookworm, Toxocara vitulorum on cow feces and cattle ranchers in Karangnongko village, Boyolali. Sampling using random sampling technique. The research was conducted in the parasitology laboratory of Setia Budi University with the direct method of using $2 \%$ lugol and observed microscopically. The results of research positive percentage in cow feces isHookworm 8\%, Toxocaravitulorum 4\%, whereas in faeces breeders are not found Hookworm worm egg infection, Toxocaravitulorum.
\end{abstract}

Keywords: Hookworm, Toxocaravitulorum, Cows.

\section{PENDAHULUAN}

Sapi merupakan salah satu komoditi dalam bidang peternakan yang memiliki produk aktif berupa susu. Tingginya kesadaran masyarakat akan pentingnya protein yang terkandung didalam susu menjadikan susu sebagai produk hasil peternakan yang sangat diminati. Menurut data Kementerian Pertanian Republik Indonesia (2017), jumlah populasi sapi di Indonesia saat ini mecapai 14,6 juta ekor atau masih memenuhi sekitar 67\% kebutuhan sapi di Indonesia.

Peternakan yang dipelihara secara tradi- sional maupun modern tidak dapat lepas dari berbagai hambatan termasuk penyakit akibat cacing parasit berupa nematoda dan cestoda. Menurut data World Health Organization (WHO) tahun 2016, terdapat lebih dari 1,5 miliyar orang atau sekitar $24 \%$ penduduk di dunia terinfeksi Soil Transmitted Helminth dan yang terinfeksi taeniasis sebanyak 2,8 miliyar orang.

Kabupaten Boyolali terkenal sebagai penghasil susu terbesar di Jawa Tengah. Dusun Karangnongko merupakan salah satu daerah di 
Boyolali yang menghasilkan produk susu. Kondisi kandang sapi yang berdekatan dengan rumah peternak sapi serta sanitasi peternakan yang masih buruk menjadi pertimbangan untuk melakukan penelitian sebagai upaya pencegahan infeksi penyakit akibat cacing sebelum terjadi infeksi.

Tujuan dari penelitian ini adalah untuk mengetahui apakah terdapat infeksi telur cacing Hookworm, Toxocara vitulorum pada feses sapi dan peternak sapi, serta untuk mengetahui prosentase infeksi telur cacing Hookworm, Toxocara vitulorum pada feses sapi dan peternak sapi. Manfaat dari penelitian ini adalah memberikan pengetahuan bagi mahasiswa tentang prosentase infeksi cacing, memberikan pemahaman kepada masyarakat khususnya peternak sapi agar dapat melakukan tindakan pencegahan terhadap bahaya infeksi cacing Hookworm, Toxocara vitulorum, serta sebagai referensi penelitian selanjutnya bagi mahasiswa.

\section{METODE PENELITIAN}

\section{Alat dan Bahan Penelitian}

Alat : Pot sampel, mikroskop, obyek glass, masker, handscoon, lidi.Bahan :Sampel feses sapi dan peternak sapi, larutan lugol 2\%

\section{Prosedur Kerja}

\section{a. Pemeriksaan Makroskopis}

1) Membuka pot sampel yang berisi feses

2) Mengamati warna, bau, konsistensi, ada tidaknya lendir, darah dan cacing dewasa

\section{b. Pemeriksaan Mikroskopis}

1) Meneteskan 1 tetes Lugol $2 \%$ di atas obyeckglass

2) Mengambil sampel feses seujung sudip atau $\pm 2 \mathrm{mg}$, meletakkan diatas obyeck glass

3) Menghomogenkan feses dengan larutan lugol $2 \%$ menggunakan lidi

4) Menutup sedian dengan deck glass atau kaca penutup

5) Memeriksa sediaan di bawah mikroskop dengan lensa obyektif dengan perbesaran 100 atau 400.

\section{Prosentase Infeksi}

Jumlah sample feses ternak yang terkontaminasi Jumlah sample feses yang diperiksa

\section{HASIL DAN PEMBAHASAN}

Hasil penelitian secara makroskopis pada 5 feses peternak sapi yaitu warna feses kuning kecoklatan dengan bau khas feses, konsistensi lembek dan agak keras, tidak ditemukan adanya lendir, darah dan cacing dewasa. Pemeriksaan makroskopis pada 25 feses sapi yaitu warna feses kehitaman dengan bau khas feses sapi, konsistensi lembek, serta tidak ditemukan adanya lendir, darah, dan cacing dewasa pada feses.

Pemeriksaan mikroskopis pada sampel feses sapi ditemukan telur cacing Hookworm, telur cacing Toxocara vitulorum, dan larva filariform Hookworm,sedangkan pada feses peternak sapi tidak ditemukan telur cacing Hookworm, Toxocara vitulorum dan Taenia saginata.

Pemeriksaan ini dilakukan dengan metode pemeriksaan langsung. Metode pemeriksaan langsung dilakukan dengan 2 tahap pemeriksaan yaitu pemeriksaan makroskopis dan mikroskopis. Pemeriksaan makroskopis harus dilakukan terlebih dahulu untuk melihat kemungkinan adanya infeksi cacing pada feses. Pemeriksaan makroskopis dilakukan dengan mengamati warna, bau, konsistensi, serta ada tidaknya darah, lendir, dan cacing dewasa yang ada pada feses. Pemeriksaan mikroskopis dilakukan dengan cara diambil tinja kira-kira 0,2 gram, diletakkan pada Obyek glass. Kemudian ditambah 1-2 tetes Lugol 2\% dan diratakan, lalu ditutup dengan Deck glass atau kaca penutup dan langsung diperiksa dibawah mikroskop perbesaran lemah $(10 \times 10)$ dan perbesaran sedang (40 x 10) (Gandasoebrata, 2008).

Pemeriksaan makroskopis pada 5 feses peternak sapi didapatkan hasil sebagai berikut: warna kuning kecoklatan dengan bau khas 
feses. Konsistensi lembek dan agak keras, serta pada feses tidak terdapat lendir, darah dan cacing dewasa. Hasil pemeriksaan tersebut dapat disimpulkan bahwa feses peternak sapi normal dan tidak adanya infeksi telur cacing. Pemeriksaan makroskopis pada 25 feses sapi didapatkan hasil sebagai berikut: warna feses kehitaman dan memiliki bau khas feses sapi dengan konsistensi lembek, tidak ditemukan adanya lendir, darah, dan cacing dewasa pada feses.

Hasil penelitian pada sampel feses sapi dan peternak sapi di Dusun Karangnongko RT 03/ RW 01, Desa Karangnongko, Kecamatan Mojosongo, Kabupaten Boyolali menunjukkan bahwa dari 25 sampel feses sapi terdapat 3 sampel yang terinfeksi telur cacing terdiri dari 2 telur cacing Hookworm dan 1 telur cacing Toxocara vitulorum. Pada 5 sampel feses peternak sapi tidak ditemukan telur cacing Hookworm, Toxocara vitulorum,

Telur cacing Hookworm yang ditemukan pada feses sapi memiliki morfologi telur berukuran $\pm 70 \times 45 \mu$, bulat lonjong, berdinding tipis, kedua kutub mendatar, di dalamnya terdapat beberapa sel. Ditemukan juga telur Toxocara vitulorum pada feses sapi dengan morfologi telur berukuran $\pm 80 \times 70 \mu$, bulat, dinding luar menyerupai renda. Sampel feses sapi juga ditemukan larva filariform Hookworm dengan morfologi panjang $\pm 500 \mu$, ruang mulut tertutup, esofagus menempati $1 / 4$ panjang badan bagian anterior (Prianto dkk, 2008). Pemeriksaan mikroskopis pada sampel feses peternak sapi tidak ditemukan telur cacing Hookworm, Toxocara vitulorum.

Hubungan antara sapi dengan peternak sapi yaitu kandang sapi yang berdekatan dengan rumah peternak, sering terjadi kontak antara ternak sapi dan peternak sapi. Pencegahan yang dapat dilakukan untuk mencegah terjadinya infeksi kecacingan pada sapi maupun peternak sapi yaitu menjaga hygiene dan sanitasi, tidak defekasi di sembarang tempat, mencuci tangan dengan sabun sebelum dan sesudah makan, dan tidak menggunakan tinja manusia sebagai pupuk (Safar, 2009).

\section{KESIMPULAN}

1. Terdapat infeksi telur cacing Hookworm dan Toxocara vitulorum dengan prosentase infeksi $8 \%$ dan $4 \%$, pada feses sapi

2. Tidak terdapat infeksi telur cacing Hookworm, Toxocara vitulorum pada feses peternak sapi.

\section{DAFTAR PUSTAKA}

Agustina, K., Dharmayudha., Wirata, I. 2013. "Prevalensi Toxocara vitulorum Pada Induk dan Anak Sapi Bali di Wilayah Bali Timur". Buletin Veteriner Udayana. Vol 5 (1): $1-6$

Gandasoebrata, R. 2008. Penuntun Laboratorium Klinik edisi kelima, Dian Rakyat: Jakarta

Hariani, B. 2015. "Keberadaan Telur dan Larva Cacing Tambang Pada Tanah di Lingkungan Desa Sepunggur dan Desa Gunung Tinggi Kabupaten Tanah Bumbu Kalimantan Selatan Tahun 2014”. Jurnal Vektor Penyakit. Vol (9): 15-20

Irianto, K. 2009. Parasitologi: Berbagai Penyakit yang Mempengaruhi Kesehatan Manusia. Bandung: Yrama Widya

Kementerian Pertanian Republik Indonesia. 2017. "Populasi Sapi Perah Menurut Provinsi, 2013-2017”. (Online), (http://www.pertanian.go.id/ap_pages/mod/datanak, diakses 14 November 2017)

Prianto, J., Tjahaya. P. U, Darwanto. 2008. Atlas Parasitologi Kedokteran. Jakarta: Gramedia Pustaka Utama

Safar, R. 2009. Parasitologi Kedokteran. Bandung: Yrama Widya

Tantri, N., Setyawati. T. R., Khotimah, S. 2013. "Prevalensi dan Intensitas Telur Cacing Parasit Pada Feses Sapi (Bos Sp) Rumah Potong Hewan (RPH) Kota Pontianak Kalimantan Barat". Jurnal Protobiont, 2 (2): 102-106

WHO, 2016. "Soil Transmitted Helminth Infection", (Online), (http://www.who.int/medicentere/factsheets/fs366/en/, diakses 12 November 2017) 